\title{
Modeling for mitigating storm water urban flooding and water quality issues by using small serial dams: A case study of the city of San Angelo
}

Kim T.J.

Department of Civil Engineering, Daegu University, 201 Daegudae-ro, Jillyang, Gyeongsan, Gyeongbuk, 38453, Korea

Received: 27/05/2021, Accepted: 29/07/2021, Available online: 15/08/2021

*to whom all correspondence should be addressed: e-mail: kimtj@daegu.ac.kr https://doi.org/10.30955/gnj.003745

\section{Graphical abstract}

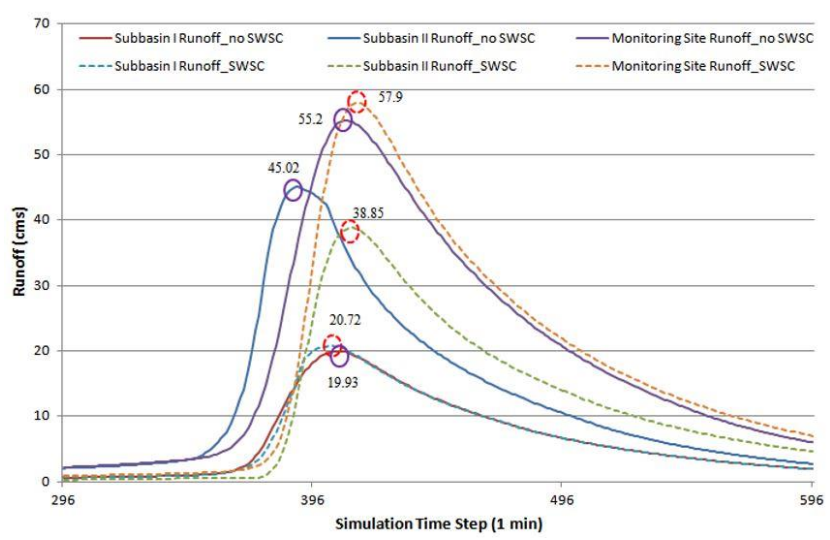

\section{Abstract}

The City of San Angelo has been imposed on urban flooding and no-point source pollution and develop storm water monitoring and modeling project for managing these storm water issues. This study focuses on the stormwater peak flow reduction and water pollutant improvement by using small serial retention structures. The storm water data collected are utilized to verify storm water and event mean concentration in SWMM model. The verified SWMM that has range from 0.6 to 0.8 of coefficient of determination is modeled to evaluate small serial dams for reducing peak flow and water quality loading. Small serial dams explain the $26 \%-55.3 \%$ peak flow reduction and $53.2 \%-93.7 \%$ water pollutant removal percent. Sensitivity analysis results for three kinds of orifice sizes provide that smaller size increases the hydraulic retention and reduces the peak flow than other bigger size while the bigger size shows effective water pollutant reduction than small size.

Keywords: Best management practice, multiple regression equation, peak flow, SWMM, water pollutants.

\section{Introduction}

The City of San Angelo (COSA) has fallen under the purview of the Phase II small Municipal Separate Storm Sewer Systems (MS4s) general permit rules promulgated by the US Environmental Protection Agency (USEPA) and administered in Texas by the Texas Commission on Environmental Quality (TCEQ) (UCRA, 2013). Also, under a National Pollutant Discharge Elimination (NPDS) System, the COSA is required to be responsible for the stormwater outfall discharged from city. Accordingly, the COSA has adopted plans to construct structure measures and initiate non-structure measure for managing stormwater.

Historically, urban storm water came from non-point sources in the COSA has impacts on streams, ponds, and lake. In particular, the downstream segment of the North Concho River has problems in fish kills, water quality issues, and atheistic condition problems. Accordingly, the COSA and Upper Colorado River Authority (UCRA) have tried to construct facilities based on USEAP grant funds and local contribution. As a result, fish kills occurred from storm water has reduced and water quality issues have improved continually. However, because of limited storm sewer system, most storm water are delivered by city streets, alleys, and natural drainage features that leads to urban flood problems as city is growing (UCRA, 2013).

The COSA and UCRA have developed a storm water monitoring and modeling projects for managing storm water related issues. Accordingly, the entire City is mapped and disaggregated into subcatchments and then some subcatchments are considered for installing storm water monitoring station and constructing Best Managements Practices (BMPs) for mitigating storm water urban flood and water quality problems. By performing these tasks, it is possible to assess existing watershed conditions, evaluate BMPs and predict the storm water and water quality changes based on land use changes in the watershed. In other words, BMPs are modeled and assessed for assisting to implement a storm water management plan that includes water quality characterization and hydrologic and water quality modeling of the urban watershed of the city using gaged storm water data (UCRA, 2013).

The selection of computer model for evaluating BMPs is important for performing these strategies such as flood 
reduction and water quality improvement in urban area. Hydraulics models (e.g. HEC-RAS), hydrology models (e.g. HEC-HMS), water quality models (e.g. STORM), and watershed models (e.g. SWMM and SWAT) can be considered. In this study, the EPA's Storm Water Management Model (SWMM) is selected because SWMM is a comprehensive hydrologic, hydraulic, and water quality simulation model developed primarily for urban areas. Also, the SWMM has been widely applied through the U.S. and Canada, and elsewhere as well. (Huber and Dickinson, 1988; Rossman, 2009). Further, SWMM is a public domain model, with capabilities to simulate typical wet or dry pond BMPs, and it uses a time step of less than one day, which is critical to the dynamics of storm flows for small urban catchments (UCRA, 2013). In this study, three modeling tasks are performed as follows: 1) verification of SWMM model to storm water flows obtained at monitoring locations operated by the UCRA, 2) development of a water quality modeling component using storm water quality data collected by UCRA, 3) application of the urban water quantity/quality model to evaluate small serial dams as BMPs.

\section{Case study area}

City of San Angelo is located on the southwestern edge of the Edwards Plateau and the northeastern edge of the Chihuahuan desert at the juncture of the North and South Concho Rivers that is roughly outlined by Tom Green County, Texas. Three lakes that are Twin Buttes Reservoir, O.C. Fisher Reservoir, and Lake Nasworthy are used for supplying water for various purposes in the city of San Angelo. The COSA area is delineated into subcatchments using ArcSWAT based on 30-meter resolution Digital Elevation Models (DEMs). The subcatchment delineation is based on defining outlets that include 10 permanent monitoring stations, 12 temporary monitoring stations, and 23 other points of interests (UCRA, 2013). Seven BMPs are considered to be installed above seven permanent stations to reduce storm water urban flooding and improve water quality.
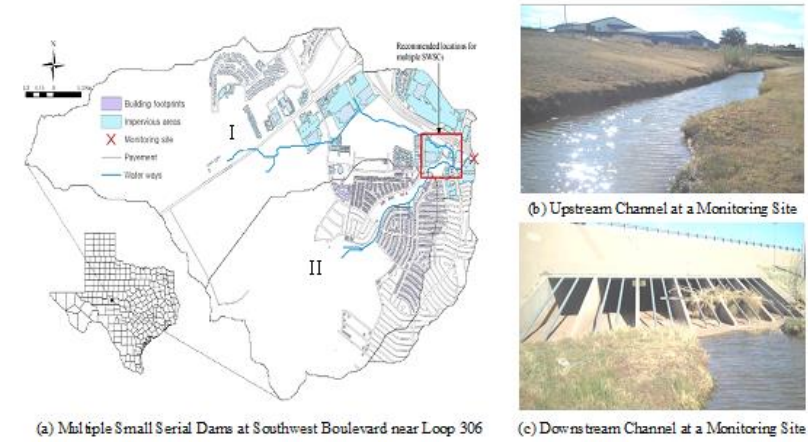

Figure 1. Subcatchments above a Monitoring Site in San Angelo, TX.

The critical urgent site for water quality and urban flooding within the COSA is located at Southwest Boulevard near Loop 306 (Fig 1. (a)). This site has long experienced serious urban flooding problems which are likely to worsen as additional development occurs within the existing sub-divisions and commercial areas. In case of intense storm events, severely inadequate storm water conduit under street causes back-up and impoundment of storm water above crossing and frequent overtopping of roadway (Figure 1. (b) and (c)). Also, water quality monitoring at this site indicates excessive contaminant loadings. Accordingly, topographic realities dictate the need for a series of dry pond facilities that not only reduce hydraulic peak for flood mitigation, but also decrease pollutant loads (COSA, 2013). In this study, series of low dams are recommended to be constructed for reduce peak flood flow and water pollutants.

\subsection{Data description}

Various input data procedures for verifying the SWMM model includes as follows: delineation of watershed, development of the drainage area above monitoring stations, land use and soil data at the sub-basin level, and monitoring of rainfall data. Two subcatchments I and II that are imposed on critical storm water urban floods are extracted from disaggregated subcatchments of the COSA. The monitoring site is located below subcatchment I and subcatchment II that is connected to subcatchment I (Figure 1(a)).

The areas of subcatchments I and II are 4.92 and $2.90 \mathrm{Km}^{2}$, respectively. The percentage (\%) of impervious areas that include building footprints, non-residential areas, and pavement for the total area of subcatchments I and II are 23.81 and 15.02, respectively. The first, second, and third highest percent values for subcatchment I were retail personal services $(11.8 \%)$, low-density residential areas $(6.2 \%)$, and medium density residential areas $(4.9 \%)$ excluding the vacant-area category (71\%), while those for subcatchment II were low-density residential areas (7.9\%), retail personal services (7.4\%), and medium-density residential areas $(4.4 \%)$ excluding the vacant-area category (84\%), respectively. These land use data were aggregated into low, medium, and high categories for developing the multiple regression equations to define water quality input to SWMM. Soil survey information indicates that Tu (Tulia loam), An (Angelo clay loam), and Rt (Rotan clay loam) have the first (29.2\%), second $(17.5 \%)$, and third (13.9\%) highest percent values of all soil types for the total area of subcatchments I and II, respectively. The soil information and the associated hydrologic soil group are used to define the suction head, conductivity, and initial deficit values in Green-Ampt infiltration methods in a SWMM model (COSA, 2013).

Rainfall is the driving input data to the SWMM model as those data are processed by the model to simulate the time-history of storm water flow and quality. Measured rainfall data collected by UCRA at 1- or 15-minutes time intervals was used as model input for the model calibration and validation process and for evaluation of potential BMPs (COSA, 2013). During measuring time, 29 storm events are occurred for June 2010-March 2012. Basic statistics for total cumulative rainfall $(\mathrm{mm})$ at a monitoring station are 17.5 mean, 106.4 maximum, 1.0 minimum and 8.9 median value. The runoffs based on measured depths are computed with channel geometry 
(m) (39.22 top, 11.30 bottom, 2.76 width), Manning's $n$ value (0.05), slope (0.005), and shape $(\mathrm{m})$ (rectangular (if $\mathrm{H}$ is blow 0.6) + Trapezoidal (if $\mathrm{H}$ is bigger than 0.6)) by using Manning's Equation. Basic runoff $\left(10^{3} \mathrm{~m}^{3}\right)$ event statistics are 27.09 mean, 173.21 maximum, 0.02 minimum, and 10.98 median.

\section{Storm water modeling}

\subsection{SWMM verification for water quantity}

SWMM has been applied to predict water quantity, i.e. peak flow, runoff depth, and time to peak, in various conditions and scenarios (Jat et al., 2009; Kim et al., 2010; Kovacs and Clement, 2009; Magill and Sansalone, 2010; Sharifan et al., 2010), route the runoff discharge (Camorani et al., 2005) and estimate water quality factors (e.g. biochemical oxygen demand and total nutrients) with considering runoff (Chang et al., 2008; Lee et al., 2009; Liu et al., 2015; Park et al., 2008; Piro et al., 2010; Taghizadeh et al., 2021; Tsihrintzis and Hamid, 1998). Besides, bioretention (Movahedinia et al., 2019), on-site flowcontrol device (Elliott et al., 2010), hydrologic impact assessment (Jang et al., 2007), retention (Cipolla, 2016), stormwater structure controls (Lowe, 2009; Lucas, 2010; Pomeroy et al., 2008) were performed using SWMM. Geographic Information System (GIS) program is used for extracting main parameters in SWMM (Barco et al., 2008; Dongquan et al., 2009; Smith et al., 2005) and its parameters are calibrated using General Regression Neural Network (Zaghloul and Kiefa, 2001) or optimized using Sequential Quadratic Programming (SQP) method as implemented in MATLAB (Choi and Ball, 2002).

In this study, SWMM model for water quantity is developed for the subcatchment above a permanent site (Figure 1. (a)) with a potential BMP that was to be evaluated for mitigating storm water urban flood and water pollutants. During verification process, small 23 rainfall events are excluded and the focus was the larger sized six rainfall events with more than $25.4 \mathrm{~mm}$ of rainfall. Because evaluation of BMP for various design storm (1year to 100 -year return frequency) is more meaningful for this study. Peak flows, total storm volumes, mean relative error(MRE), the Nash-Sutcliffe model efficiencies (NSE) (Nash and Sutcliffe, 1970), correlation coefficient $\left(R^{2}\right)$, and peak time are used to verify the SWMM model results compared with measured flows that are existing drainage condition of a permanent monitoring site.

A comparison of model predictions to measured storm flows for the verification events is provided in Table 1 for six storm events. The ranges of percentage that are expressed as surface runoff divided by total precipitation are from $12.77 \%$ (storm event 1 ) to $26.10 \%$ (storm event 6) for measured precipitation and runoff and from $12.75 \%$ (storm event 1 ) to $21.92 \%$ (storm event 4 ) for simulated precipitation and runoff. These analyses indicate that the Green-AMPT infiltration model in SWMM has been effectively established to represent the real infiltration phenomenon. Based on mean and MRE values, the simulated total runoff for four storm events except storm events 1 and 4 are under-predicted compared to measured flows. The main reason for under-prediction is that the runoff derived from the previous rainfall increases the measured total runoff volume and peak inflow, while the simulated runoff and peak flows are not increased by previous rainfall events because of a single design storm event. $\mathrm{R}^{2}$ values range from 0.67 (storm event 2) to 0.86 (storm events 1 and 5), and NSE values range from 0.69 (storm event 2) to 0.87 (storm event 1 ). The simulated time to peak runoff occurred within about the same time (storm event 6 ) to within 50 minutes later (storm event 5) than the measured time to peak. For the biggest storm event that occurred on August 13, 2011, the $\mathrm{R}^{2}$ and NSE values were 0.77 and 0.73 , respectively, providing a reasonable match between the largest measured and simulated runoff. The delay time difference between measured and simulated peak flow is 10 minutes. The standard deviation for measured flow ranges from 0.569 (storm event 6) to 3.669 (storm event 4), while that for simulated flow ranges from 0.328 (storm event 6 ) to 4.080 (storm event 5). Also, the median flows for measured and simulated flows show similar results. For the large storm event, the simulated median flow is $12.5 \%$ lower than the measured median flow. These criteria comparison results indicated that the SWMM model is verified for representing the measured runoff.

\subsection{SWMM event mean concentration for water quality}

The monitoring site collects total suspended solids (TSS), total phosphorus (TP), 5-day biochemical oxygen demand (BOD5), and total nitrogen (TN) as determined from nitrite-nitrate nitrogen plus total Kjeldahl nitrogen that represents event mean concentrations (EMCs). Accordingly, the EMC option that user specify as input a concentration of SWMM was employed for the water quality modeling. However, without BMP processes that reduce water pollutants loadings, the SWMM model predicts simulated concentration similar or same to input concentrations (UCRA, 2013).

Equations for TSS, TN, TP, and BOD (Eq. 1) were developed using multiple regression technique for reflecting land uses and rainfall intensity. Land use categories are aggregated into low intensity land use (agriculture land use, public and vacant), moderate intensity land use (park recreation and others) and high intensity land use (remaining land use). Rainfall-runoff storm erosivity (EI) factor is calculated using Eq. 2. Coefficients in multiple regression equation are developed by using SAS statistical program (Table 2).

$$
\begin{aligned}
E M C= & A *(\text { Antecedent days })+\mathrm{B}^{*}(\mathrm{EI}) \\
& +\mathrm{C} *(\text { Low })+\mathrm{D} * \text { (Moderate })+\mathrm{E} *(\text { High }) \\
E I_{30}= & (E)\left(I_{30}\right)=\left(\sum_{r=1}^{n} e_{r} \Delta V_{r}\right) l_{30}
\end{aligned}
$$

Where, $E_{30}$ is storm erosivity (hundred of $\mathrm{m} \cdot$ tonf/ $\left.\mathrm{km}^{2} / \mathrm{mm}\right)$; tonf is tons-force; $E$ is storm kinetic energy $\left(\mathrm{m} \cdot\right.$ tonf $\left./ \mathrm{km}^{2}\right) ; l_{30}$ is maximum 30 -min rainfall intensity $(\mathrm{mm} / \mathrm{h}) ; \quad e_{r}$ is rainfall kinetic energy $\left(1,099 \times\left[1-0.72 \times \exp \left(-1.27 i_{r}\right)\right]\right) ; i_{r}$ is rainfall intensity; $\Delta V_{r}$ is depth of rainfall $\left(i_{r} \cdot \Delta t_{r}\right) ; \Delta t_{r}$ is duration of the increment (15 minutes) used in the rainfall data collection; and $r$ is the $r^{\text {th }}$ increment out of a total of $n$ increments. 
Table 1. Comparison of measured and simulated runoff characteristics at a monitoring site

\begin{tabular}{|c|c|c|c|c|c|c|c|c|c|c|c|c|}
\hline \multirow{3}{*}{$\begin{array}{c}\text { Storm } \\
\text { event }\end{array}$} & \multicolumn{2}{|c|}{1} & \multicolumn{2}{|c|}{2} & \multicolumn{2}{|c|}{3} & \multicolumn{2}{|c|}{4} & \multicolumn{2}{|c|}{5} & \multicolumn{2}{|c|}{6} \\
\hline & \multicolumn{2}{|c|}{$8 / 24 / 2010$} & \multicolumn{2}{|c|}{$9 / 25 / 2010$} & \multicolumn{2}{|c|}{$10 / 23 / 2010$} & \multicolumn{2}{|c|}{$8 / 13 / 2011$} & \multicolumn{2}{|c|}{$10 / 8 / 2011$} & \multicolumn{2}{|c|}{$1 / 24 / 2012$} \\
\hline & $\begin{array}{c}\text { Meas } \\
\text { ured }\end{array}$ & $\begin{array}{c}\text { Simul } \\
\text { ated }\end{array}$ & $\begin{array}{c}\text { Meas } \\
\text { ured }\end{array}$ & $\begin{array}{c}\text { Simul } \\
\text { ated }\end{array}$ & $\begin{array}{c}\text { Meas } \\
\text { ured }\end{array}$ & $\begin{array}{c}\text { Simul } \\
\text { ated }\end{array}$ & $\begin{array}{c}\text { Meas } \\
\text { ured }\end{array}$ & $\begin{array}{c}\text { Simul } \\
\text { ated }\end{array}$ & $\begin{array}{c}\text { Meas } \\
\text { ured }\end{array}$ & $\begin{array}{c}\text { Simul } \\
\text { ated }\end{array}$ & $\begin{array}{c}\text { Meas } \\
\text { ured }\end{array}$ & $\begin{array}{l}\text { Simul } \\
\text { ated }\end{array}$ \\
\hline $\begin{array}{l}\text { Rainfall } \\
\text { (mm) }\end{array}$ & 29.00 & - & 36.3 & - & 42.9 & - & 106.4 & - & 60.2 & - & 40.4 & - \\
\hline \multicolumn{13}{|l|}{ Mean } \\
\hline $\begin{array}{l}\text { Flow } \\
\text { (cms) }\end{array}$ & 0.385 & 0.389 & 0.814 & 0.560 & 0.805 & 0.617 & 0.929 & 1.074 & 0.257 & 0.193 & 0.253 & 0.132 \\
\hline $\begin{array}{c}\text { S.D } \\
\text { (cms) }\end{array}$ & 0.746 & 0.803 & 1.795 & 1.215 & 1.798 & 1.478 & 3.669 & 4.080 & 0.657 & 0.500 & 0.569 & 0.328 \\
\hline \multicolumn{13}{|l|}{ Median } \\
\hline $\begin{array}{l}\text { Flow } \\
\text { (cms) }\end{array}$ & 0.028 & 0.047 & 0.058 & 0.059 & 0.036 & 0.049 & 0.043 & 0.037 & 0.002 & 0.003 & 0.010 & 0.005 \\
\hline \multicolumn{13}{|l|}{ Peak } \\
\hline $\begin{array}{l}\text { Flow } \\
\text { (cms) }\end{array}$ & 3.00 & 3.53 & 9.18 & 5.63 & 7.89 & 7.33 & 30.17 & 28.36 & 3.89 & 2.88 & 3.03 & 2.11 \\
\hline $\begin{array}{c}\text { Volume } \\
\left(\mathrm{m}^{3}\right)\end{array}$ & 31,172 & 31,482 & 58,540 & 40,365 & 12,708 & 9,741 & 33,852 & 39,125 & 18,615 & 13,970 & 17,598 & 9,196 \\
\hline MRE & - & 0.01 & - & -0.31 & - & -0.23 & - & 0.16 & - & -0.25 & - & -0.48 \\
\hline $\mathrm{R}^{2}$ & - & 0.86 & - & 0.67 & - & 0.81 & - & 0.77 & - & 0.86 & - & 0.83 \\
\hline NSE & - & 0.87 & - & 0.69 & - & 0.83 & - & 0.73 & - & 0.84 & - & 0.72 \\
\hline $\begin{array}{l}\text { Peak } \\
\text { time }\end{array}$ & $20: 41$ & $21: 15$ & $13: 41$ & $14: 09$ & $10: 15$ & $10: 25$ & $10: 50$ & $11: 00$ & $14: 30$ & $15: 20$ & 2:55 & $2: 55$ \\
\hline
\end{tabular}

Table 2. Multiple regression equation coefficients for each variable

\begin{tabular}{cccccc}
\hline \multirow{2}{*}{ Pollutant } & \multirow{2}{*}{ Antecedent Days } & \multirow{2}{*}{ EI } & \multicolumn{3}{c}{ Land Use Intensity } \\
\cline { 3 - 6 } & & & Low & Moderate & High \\
\hline TSS & 4.32550 & 1.92534 & 2.03857 & -2.33160 & 0.02494 \\
\hline TP & 0.00677 & 0.00283 & 0.00298 & -0.00190 & 0.00224 \\
\hline TN & 0.02193 & 0.00403 & 0.01686 & 0.02268 & 0.02701 \\
\hline BOD & 0.07979 & -0.14819 & 0.19683 & 0.11767 & 0.25310 \\
\hline
\end{tabular}

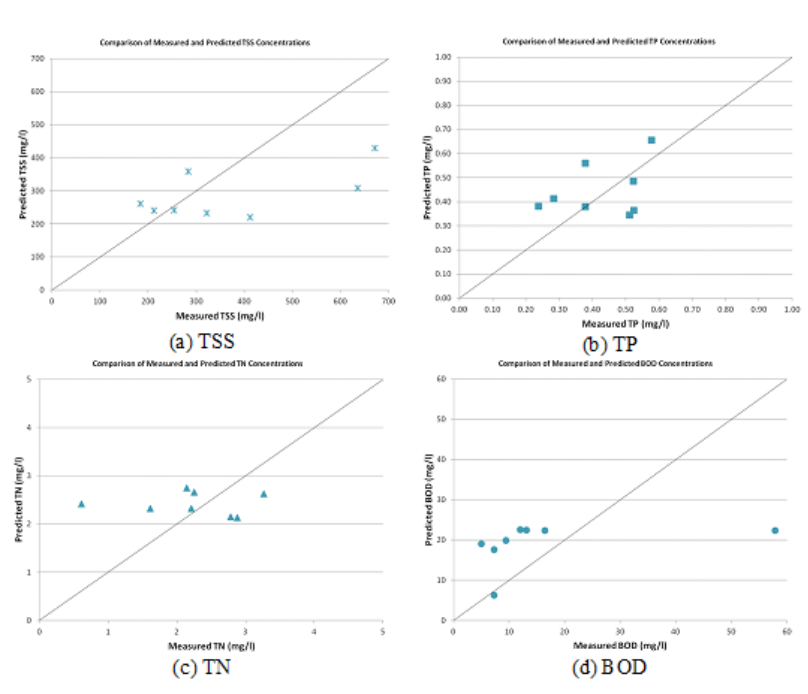

Figure 2. Comparison of Measured EMCs and Predicted EMCs.

It is apparent that the regression equations give a reasonable prediction of EMCs for the monitored storm event because the regression equation results capture the median concentration well but do not provide results that have the range of concentrations found in the measure data (Figure 2). This weakness of underestimating the variability in the data is most obvious for TSS, TN, and BOD whereas TP prediction more closely reflect the range of the observed data. This weakness of the regression equation approach is to be expected since we do not capture all the factors that may impact measured values. Despite the apparent weaknesses the regression equation for each pollutant does provide a reasonable prediction of EMCs and is sensitive to change in rainfall intensity and land use intensity (UCRA, 2013).

\section{Best management practice (BMP) application}

It is very uncertain to estimate the initial amount of water release through retention structure that depends on rainfall intensity, dam size, peak runoff, total amount, and so on. In this study, orifice and weir features with storage unit in SWMM model are utilized for modeling the water release from dam and emergency spillway, respectively. The orifice "bottom" type and "closed rectangular" shape in SWMM model are selected and the discharge coefficient uses the default value (i.e. 0.65). The orifice size is assumed as $1 \%$ of total area dam. The weir type is 
trapezoidal with zero side slope and $0.9 \mathrm{~m}$ inlet offset, and the discharge coefficient for central portion of weir also uses default value (i.e. 3.33). The weir size follows the dam length and height (e.g. $37.2 \mathrm{~m} \times 0.9 \mathrm{~m}$ ). The design rainfall events were determined for a Type-II design rainfall (Frederick et al., 1977; Hershfield, 1961) at 15minute intervals for a 12-hour duration storm return intervals for two situations: 1) 1, 5, 10, 25, 50, and 100 design year for water quantity; and 2) 1 and 5 design year for water quality.

\subsection{Storm water urban flooding evaluation}

Seven Storm Water Structure Controls (SWSCs) on the north tributary and five SWSCs on the south tributary were evaluated for the effectiveness of peak flow reduction with $1,5,10,25,50$, and 100 design storm events (Table 3). For most cases, the use of more SWSCs resulted in a greater peak flow reduction and increased peak time delay. However, two small serial structures for 50 and 100 design storm events, and three small serial structures for 100-year design storm events at the north tributary, provide the opposite results, in that the peak flow at monitoring site is increased. The reason is that the peak flow is delayed by the small serial structures at the north tributary combined with the peak flow at the south tributary.

Table 3. SWMM prediction for peak flow and peak time

\begin{tabular}{|c|c|c|c|c|c|c|c|c|c|c|c|c|c|}
\hline & & \multicolumn{7}{|c|}{ Number of small serial SWSC at North Tributary } & \multicolumn{5}{|c|}{$\begin{array}{c}\text { Number of small serial SWSC at South } \\
\text { Tributary }\end{array}$} \\
\hline & & 1 & 2 & 3 & 4 & 5 & 6 & 7 & 1 & 2 & 3 & 4 & 5 \\
\hline $\begin{array}{c}\text { SWSC } \\
\text { capacity }\end{array}$ & (cms) & 518 & 518 & 518 & 446 & 539 & 446 & 446 & 680 & 552 & 616 & 934 & 743 \\
\hline \multirow[b]{2}{*}{$\begin{array}{l}\text { Design } \\
\text { Storm }\end{array}$} & Peak & \multicolumn{7}{|c|}{ Percentage of reduction } & \multicolumn{5}{|c|}{ Percentage of reduction } \\
\hline & $\begin{array}{l}\text { flow } \\
\text { (cms) }\end{array}$ & $(\%)$ & $(\%)$ & $(\%)$ & $(\%)$ & $(\%)$ & (\%) & $(\%)$ & (\%) & (\%) & $(\%)$ & $(\%)$ & (\%) \\
\hline 1 & 5.4 & $49 \%$ & $67 \%$ & $70 \%$ & $69 \%$ & $69 \%$ & $69 \%$ & $70 \%$ & $26 \%$ & $26 \%$ & $26 \%$ & $26 \%$ & $25 \%$ \\
\hline 5 & 14.6 & $19 \%$ & $26 \%$ & $43 \%$ & $47 \%$ & $53 \%$ & $59 \%$ & $61 \%$ & $24 \%$ & $28 \%$ & $28 \%$ & $28 \%$ & $27 \%$ \\
\hline 10 & 20.4 & $1 \%$ & $12 \%$ & $27 \%$ & $30 \%$ & $36 \%$ & $44 \%$ & $46 \%$ & $23 \%$ & $30 \%$ & $31 \%$ & $31 \%$ & $30 \%$ \\
\hline 25 & 31.7 & $-5 \%$ & $1 \%$ & $10 \%$ & $13 \%$ & $19 \%$ & $26 \%$ & $28 \%$ & $15 \%$ & $27 \%$ & $33 \%$ & $33 \%$ & $32 \%$ \\
\hline 50 & 42.3 & $-6 \%$ & $-4 \%$ & $3 \%$ & $5 \%$ & $9 \%$ & $14 \%$ & $15 \%$ & $10 \%$ & $20 \%$ & $31 \%$ & $34 \%$ & $33 \%$ \\
\hline \multirow[t]{2}{*}{100} & 55.2 & $-6 \%$ & $-5 \%$ & $-1 \%$ & $1 \%$ & $3 \%$ & $7 \%$ & $8 \%$ & $8 \%$ & $16 \%$ & $25 \%$ & $34 \%$ & $34 \%$ \\
\hline & Peak & \multicolumn{7}{|c|}{ Adjusted peak time } & \multicolumn{5}{|c|}{ Adjusted peak time } \\
\hline $\begin{array}{l}\text { Design } \\
\text { Storm }\end{array}$ & $\begin{array}{l}\text { time } \\
\text { (hh/ } \\
\mathrm{mm} \text { ) }\end{array}$ & $\begin{array}{l}\mathrm{hh} / \\
\mathrm{mm})\end{array}$ & $\begin{array}{l}\text { (hh/ } \\
\mathrm{mm})\end{array}$ & $\begin{array}{l}\text { (hh/ } \\
\mathrm{mm})\end{array}$ & $\begin{array}{l}\text { (hh/ } \\
\mathrm{mm})\end{array}$ & $\begin{array}{l}\text { (hh/ } \\
\mathrm{mm})\end{array}$ & $\begin{array}{l}\text { (hh/ } \\
\mathrm{mm})\end{array}$ & $\begin{array}{l}\mathrm{hh} / \\
\mathrm{mm})\end{array}$ & $\begin{array}{l}\text { (hh/ } \\
\mathrm{mm})\end{array}$ & $\begin{array}{l}\text { (hh/ } \\
\mathrm{mm})\end{array}$ & $\begin{array}{l}\text { (hh/ } \\
\mathrm{mm})\end{array}$ & $\begin{array}{l}\text { (hh/ } \\
\mathrm{mm})\end{array}$ & $\begin{array}{l}\text { (hh/ } \\
\mathrm{mm})\end{array}$ \\
\hline 1 & $6: 59$ & $7: 30$ & $7: 20$ & $7: 11$ & 7:06 & 7:05 & 7:03 & 7:01 & $6: 59$ & $6: 58$ & $6: 58$ & $6: 58$ & $6: 56$ \\
\hline 5 & $6: 49$ & $6: 58$ & $7: 10$ & $7: 32$ & $7: 43$ & $7: 58$ & $8: 18$ & $8: 27$ & 6:49 & $6: 47$ & $6: 47$ & 6:47 & $6: 46$ \\
\hline 10 & $6: 50$ & $6: 53$ & 7:04 & $7: 19$ & $7: 25$ & $7: 36$ & $7: 50$ & $7: 57$ & $6: 57$ & $6: 48$ & $6: 48$ & $6: 48$ & $6: 47$ \\
\hline 25 & $6: 50$ & $6: 51$ & $6: 57$ & 7:07 & $7: 12$ & $7: 20$ & $7: 31$ & $7: 35$ & $6: 58$ & 7:05 & $6: 48$ & $6: 48$ & $6: 48$ \\
\hline 50 & $6: 50$ & $6: 50$ & $6: 55$ & 7:02 & 7:06 & $7: 12$ & $7: 19$ & $7: 23$ & $6: 56$ & 7:04 & $7: 13$ & $6: 48$ & $6: 47$ \\
\hline 100 & $6: 49$ & $6: 50$ & $6: 53$ & 6:59 & $7: 02$ & 7:06 & $7: 12$ & $7: 15$ & $6: 54$ & 7:01 & $7: 10$ & $6: 47$ & $6: 46$ \\
\hline
\end{tabular}

Figure 3 provides additional information of this unanticipated impact. Without SWSCs, the peak flows at the north and south tributaries are 45.02 and $19.93 \mathrm{cms}$, respectively, which lead to only a peak of $55.2 \mathrm{cms}$ at monitoring site because of differences in peak time at each tributary for the 100-year design storm. However, by adding the small serial structure at the north tributary, the peak time at the north tributary is delayed to almost the same peak time at the south tributary, even though the peak flow at the north tributary is reduced to $14 \%$. The concurrent occurrences of peak time at each tributary resulted in an increase in the peak flow at monitoring site. For the south tributary, peak flow reduction and peak flow delay do not show differences between four and five structures. However, the reduction percentage increases as the recurrence year of the design storm increases, which are the reverse of the results of SWSC performance on the north tributary. The reason is that the simulated peak time with SWSCs only on the south tributary results from the peak time of peak flow at monitoring site derived from the peak flow of the north tributary. In other words, the peak time adjusted by the construction of SWSCs on the south tributary is almost the same as the time of peak flow with no construction of SWSCs, but the peak flow at monitoring site is derived from the peak flow of the north tributary. This analysis indicates that a single storm event of a design storm is not a representative storm event, but is regarded as one of the indicators that help in the evaluation of the effectiveness of a structure.

For composite SWSCs for both tributaries based on the reverse impact of SWSCs that were applied only for each tributary, the construction of three or fewer SWSCs at north tributary leads to the increase of peak flow and requires the construction of more than three SWSCs. Also, the construction of more than four SWSCs at the south tributary does not guarantee the reduction of peak flow. With these analyses of the simulated results, more than three SWSCs at the north tributary and more than one but 
less than five SWSCs at the south tributary are recommended as the appropriate numbers of SWSCs for reducing the peak flow in this study. Table 4 provides the results of peak flow reduction and peak time delay at a monitoring site. All cases show the effectiveness of peak flow reduction and peak flow delay. The percentage of peak flow reduction decreases and the peak delay time is shortened as the design storm increases. For 1, 5, 10, 25, 50 , and 100 year design storms, $7 \times 2,6 \times 4,6 \times 2(5 \times 4), 4 \times 4$, $4 \times 4$, and $4 \times 4$ composite SWSCs each at the north and south tributaries show the highest peak flow reductions of $80.6 \%, 63.6 \%, 56.2 \%, 34.2 \%, 23.3 \%$, and $14.3 \%$, respectively. The use of more small serial structures results in greater peak flow delay times, except for the Iyear design storm.

Table 4. Composite BMP predictions for peak flow and peak time

\begin{tabular}{|c|c|c|c|c|c|c|c|c|c|}
\hline \multirow{2}{*}{$\begin{array}{l}\text { Design } \\
\text { storm }\end{array}$} & \multirow{2}{*}{$\begin{array}{c}\text { \# of SWSCs on } \\
\text { South } \\
\text { Tributary }\end{array}$} & \multicolumn{4}{|c|}{$\begin{array}{c}\text { Percentage of peak flow reduction (\%) \# of SWSCs } \\
\text { on North Tributary }\end{array}$} & \multicolumn{4}{|c|}{$\begin{array}{c}\text { Delay time of peak flow }(\mathrm{hh} / \mathrm{mm}) \# \text { of SWSCs } \\
\text { on North Tributary }\end{array}$} \\
\hline & & 4 & 5 & 6 & 7 & 4 & 5 & 6 & 7 \\
\hline \multirow{3}{*}{$1 \mathrm{yr}$} & 2 & $74.6 \%$ & $76.5 \%$ & $79.5 \%$ & $80.6 \%$ & $4: 14$ & $3: 40$ & $6: 13$ & $7: 27$ \\
\hline & 3 & $72.0 \%$ & $74.8 \%$ & $73.6 \%$ & $80.0 \%$ & 4:17 & 4:14 & $4: 14$ & $7: 26$ \\
\hline & 4 & $71.3 \%$ & $73.6 \%$ & $76.8 \%$ & $79.2 \%$ & $4: 23$ & $4: 40$ & $4: 39$ & $7: 25$ \\
\hline \multirow{3}{*}{$5 y r$} & 2 & $48.8 \%$ & $50.9 \%$ & $55.5 \%$ & $57.1 \%$ & $0: 57$ & $1: 08$ & $1: 25$ & $1: 33$ \\
\hline & 3 & $56.7 \%$ & $57.1 \%$ & $61.3 \%$ & $59.1 \%$ & 1:00 & 1:10 & $1: 30$ & 1:35 \\
\hline & 4 & $59.1 \%$ & $61.3 \%$ & $63.6 \%$ & $63.1 \%$ & $0: 55$ & $1: 08$ & $1: 31$ & $1: 36$ \\
\hline \multirow{3}{*}{$10 \mathrm{yr}$} & 2 & $31.1 \%$ & $33.6 \%$ & $39.5 \%$ & $41.8 \%$ & $0: 39$ & $0: 47$ & $0: 59$ & 1:04 \\
\hline & 3 & $40.0 \%$ & $38.4 \%$ & $56.2 \%$ & $41.8 \%$ & $0: 48$ & $0: 52$ & 1:01 & 1:06 \\
\hline & 4 & $47.8 \%$ & $56.2 \%$ & $50.8 \%$ & $48.8 \%$ & $0: 37$ & $0: 47$ & $1: 10$ & $1: 14$ \\
\hline \multirow{3}{*}{$25 y r$} & 2 & $15.5 \%$ & $17.9 \%$ & $22.8 \%$ & $24.1 \%$ & $0: 26$ & $0: 31$ & $0: 41$ & $0: 44$ \\
\hline & 3 & $21.2 \%$ & $20.8 \%$ & $23.1 \%$ & $23.8 \%$ & $0: 31$ & $0: 35$ & $0: 42$ & 0:45 \\
\hline & 4 & $34.2 \%$ & $31.1 \%$ & $28.8 \%$ & $27.9 \%$ & $0: 44$ & $0: 45$ & $0: 48$ & $0: 49$ \\
\hline \multirow{3}{*}{$50 \mathrm{yr}$} & 2 & $7.2 \%$ & $9.1 \%$ & $12.5 \%$ & $14.1 \%$ & $0: 19$ & $0: 23$ & $0: 29$ & $0: 32$ \\
\hline & 3 & $12.1 \%$ & $11.9 \%$ & $13.1 \%$ & $13.8 \%$ & $0: 23$ & $0: 26$ & $0: 31$ & 0:34 \\
\hline & 4 & $23.3 \%$ & $20.7 \%$ & $18.3 \%$ & $18.0 \%$ & $0: 33$ & $0: 34$ & $0: 35$ & $0: 38$ \\
\hline \multirow{3}{*}{$100 \mathrm{yr}$} & 2 & $2.2 \%$ & $3.2 \%$ & $5.9 \%$ & $7.2 \%$ & $0: 15$ & $0: 18$ & $0: 23$ & $0: 26$ \\
\hline & 3 & $6.3 \%$ & $5.9 \%$ & $6.5 \%$ & $7.1 \%$ & $0: 19$ & $0: 21$ & $0: 25$ & $0: 27$ \\
\hline & 4 & $14.3 \%$ & $12.3 \%$ & $10.5 \%$ & $9.7 \%$ & $0: 26$ & $0: 27$ & $0: 28$ & $0: 30$ \\
\hline
\end{tabular}

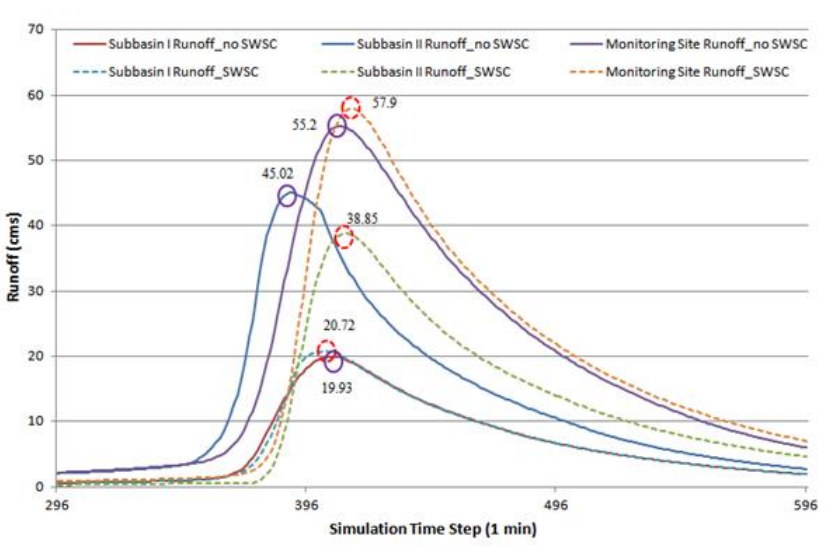

Figure 3. Comparison of peak time of peak flow without SWSC and with SWSC (i.e. two small serial structures at north tributary)

Tables 5 explains the impact of three kinds of orifice size $(0.5 \%, 1 \%$ and $2 \%)$ with three kinds of rainfall events for peak inflow and total volume at monitoring site's outlet. The peak inflows are decreased with all size of orifice but the reduction range for $0.5 \%$ orifice size has largest value than any other orifice size. Because as the smaller orifice
The most peak flow reduction at monitoring site occurred using four SWSCs at each tributary (Figure 4). For fourSWSC simulation results located in the north tributary, the $70.1 \mathrm{~m}^{3} / \mathrm{s}$ peak flow generated directly from subcatchment I is decreased by 42.2 percent to $40.5 \mathrm{~m}^{3} / \mathrm{s}$ after the $1^{\text {st }}$ SWSC operation, while the decrease of total volume is not significant because the dam and dry pool storage are modeled not to store the inflow, though channel losses somewhat decrease the total volume. The remaining SWSCs ( 2 to 4 ) have the capability to decrease the peak inflow, but the reduction percentage is lower than the first SWSC reduction percentage with more hydraulic retention time. The same results occur at the south tributary, which experienced a $42 \%$ peak flow reduction. size has, the longer the hydraulic retention time increase that have the peak flow decrease. For comparison of continuous (storm events 1-4) and design storm rainfall events, $2 \%$ of orifice size does not impact the peak flow too much for measured storm event though each peak flows for 1 and 5 year design storms have 43 and 22 percents decrease, respectively. The reason is that the continuous storm event that consists of four single events with several non-zero and zero runoff patterns do not increase the elevation of dams. It means that the water releases amounts do not overwhelmed of designed storage release capacity and are constant with different orifice size. Another reason is that measured rainfall does not have continuous rainfall interval that provides the interval time of elevation decrease while design storm rainfall provides the continuous rainfall that helps the dam effectiveness increase. For small orifice size $(0.5$ and $1 \%)$, the reduction percent of peak flow is bigger than $2 \%$ of orifice size because the hydraulic retention time is increased. Total volume is not impacted by orifice size in all cases. 
Table 5. Storm water quantity and storm water pollutant loadings simulation results

\begin{tabular}{|c|c|c|c|c|c|c|c|c|c|c|c|c|c|}
\hline \multirow[t]{5}{*}{$\begin{array}{c}\text { Orifice } \\
\text { Size }\end{array}$} & \multirow[t]{4}{*}{$\begin{array}{l}\text { Condition } \\
\text { Simulated }\end{array}$} & \multicolumn{4}{|c|}{$\begin{array}{l}\text { Measured Event (28.45 } \mathrm{mm} \\
\text { rainfall) }\end{array}$} & \multicolumn{4}{|c|}{$\begin{array}{c}\text { 1yr } 12 \mathrm{hr} \text { Event (42.16 mm } \\
\text { rainfall) }\end{array}$} & \multicolumn{4}{|c|}{$5 y r 12 \mathrm{hr}$ Event (77.72 mm rainfall) } \\
\hline & & \multicolumn{12}{|c|}{ Storm water quantity } \\
\hline & & \multicolumn{2}{|c|}{ Peak Flow } & \multicolumn{2}{|c|}{ Total Volume } & \multicolumn{2}{|c|}{ Peak Flow } & \multicolumn{2}{|c|}{ Total Volume } & \multicolumn{2}{|c|}{ Peak Flow } & \multicolumn{2}{|c|}{ Total Volume } \\
\hline & & \multicolumn{2}{|c|}{$\left(\mathrm{m}^{3} / \mathrm{s}\right)$} & \multicolumn{2}{|c|}{$\left(10^{3} \mathrm{~m}^{3}\right)$} & \multicolumn{2}{|c|}{$\left(\mathrm{m}^{3} / \mathrm{s}\right)$} & \multicolumn{2}{|c|}{$\left(10^{3} \mathrm{~m}^{3}\right)$} & \multicolumn{2}{|c|}{$\left(10^{3} \mathrm{~m}^{3} / \mathrm{s}\right)$} & \multicolumn{2}{|c|}{$\left(10^{3} \mathrm{~m}^{3}\right)$} \\
\hline & w/o BMP & \multicolumn{2}{|c|}{1.05} & \multicolumn{2}{|c|}{226.5} & \multicolumn{2}{|c|}{4.81} & \multicolumn{2}{|c|}{396.4} & \multicolumn{2}{|c|}{15.55} & \multicolumn{2}{|c|}{1302.6} \\
\hline \multirow[b]{2}{*}{$0.5 \%$} & w/ BMP & \multicolumn{2}{|c|}{0.40} & \multicolumn{2}{|c|}{169.9} & \multicolumn{2}{|c|}{1.64} & \multicolumn{2}{|c|}{396.4} & \multicolumn{2}{|c|}{11.53} & \multicolumn{2}{|c|}{1302.6} \\
\hline & $\begin{array}{l}\text { Reduction } \\
\text { (\%) }\end{array}$ & \multicolumn{2}{|c|}{62.2} & & & 65.9 & & & 0.0 & 25.9 & & & 0.0 \\
\hline & w/ BMP & 0.68 & & & & 2.15 & & & 96.4 & 11.5 & & & 02.6 \\
\hline $1 \%$ & $\begin{array}{l}\text { Reduction } \\
\text { (\%) }\end{array}$ & 35.1 & & & & 55.3 & & & 0.0 & 26.0 & & & 0.0 \\
\hline & w/ BMP & 0.99 & & & & 2.72 & & & 96.4 & 12.0 & & & 02.6 \\
\hline $2 \%$ & $\begin{array}{l}\text { Reduction } \\
\text { (\%) }\end{array}$ & 5.4 & & & & 43.5 & & & 0.0 & 22.2 & & & 0.0 \\
\hline & & & & & & Storm & Nater & ollutan & Loadings & & & & \\
\hline & & $\begin{array}{l}\text { TSS } \\
\text { (kg) }\end{array}$ & $\begin{array}{c}\mathrm{TP} \\
\text { (kg) }\end{array}$ & $\begin{array}{c}\mathrm{TN} \\
(\mathrm{kg}) \\
\end{array}$ & $\begin{array}{l}\text { BOD } \\
\text { (kg) }\end{array}$ & $\begin{array}{l}\text { TSS } \\
\text { (kg) }\end{array}$ & $\begin{array}{c}\mathrm{TP} \\
(\mathrm{kg})\end{array}$ & $\begin{array}{l}\mathrm{TN} \\
(\mathrm{kg})\end{array}$ & $\begin{array}{l}\text { BOD } \\
\text { (kg) }\end{array}$ & $\begin{array}{l}\text { TSS } \\
\text { (kg) }\end{array}$ & $\begin{array}{c}\text { TP } \\
\text { (kg) }\end{array}$ & $\begin{array}{l}\text { TN } \\
\text { (kg) }\end{array}$ & $\begin{array}{l}\text { BOD } \\
(\mathrm{kg})\end{array}$ \\
\hline & w/o BMP & $5,345.6$ & 8.6 & 58.5 & 609.2 & $15,147.3$ & 24.0 & 130.6 & $1,083.2$ & $65,198.4$ & 101.2 & 460.4 & $2,342.8$ \\
\hline & w/ BMP & 329.8 & 1.4 & 10.4 & 37.6 & $2,116.0$ & 7.7 & 41.7 & 151.5 & $15,095.5$ & 46.7 & 212.3 & 542.5 \\
\hline $0.5 \%$ & $\begin{array}{c}\text { Reduction } \\
(\%)\end{array}$ & 93.8 & 84.2 & 82.2 & 93.8 & 86.0 & 67.9 & 68.1 & 86.0 & 76.8 & 53.8 & 53.9 & 76.8 \\
\hline & w/ BMP & 335.7 & 1.4 & 10.4 & 38.1 & $2,162.7$ & 7.7 & 42.6 & 154.7 & $15,285.1$ & 47.2 & 215.5 & 549.3 \\
\hline $1 \%$ & $\begin{array}{c}\text { Reduction } \\
(\%)\end{array}$ & 93.7 & 84.2 & 82.2 & 93.7 & 85.7 & 67.9 & 67.4 & 85.7 & 76.6 & 53.4 & 53.2 & 76.6 \\
\hline & $\mathrm{w} / \mathrm{BMP}$ & 423.2 & 1.8 & 13.6 & 48.1 & $2,137.8$ & 8.2 & 44.0 & 152.9 & $15,356.8$ & 47.6 & 217.7 & 552.0 \\
\hline $2 \%$ & $\begin{array}{l}\text { Reduction } \\
\text { (\%) }\end{array}$ & 92.1 & 78.9 & 76.7 & 92.1 & 85.9 & 66.0 & 66.3 & 85.9 & 76.4 & 52.9 & 52.7 & 76.4 \\
\hline
\end{tabular}

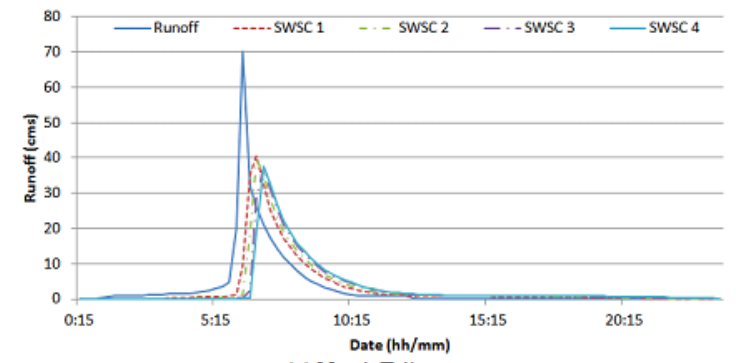

(a) North Tributary

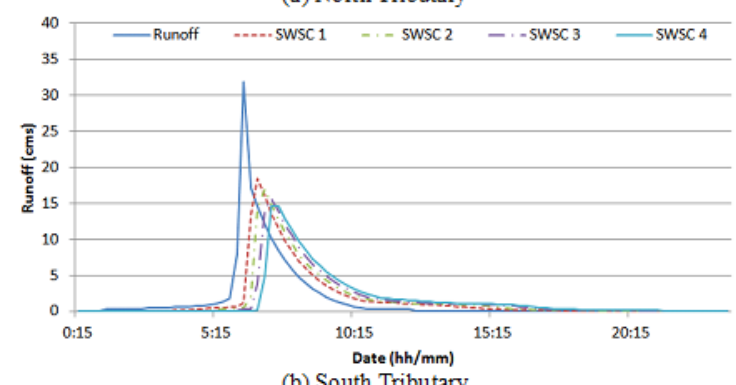

(b) South Tributary

Figure 4. Peak flow reduction efficiency with small serial dams for 100 year 12 -hr design storm.

\subsection{Water pollutant evaluation}

TSS, BOD, TP and TN removal equation for wet and dry pond storage unit were developed. Separate removal equations were developed for TSS/BOD (Eq. 3) and TP/TN (Eq. 4) (UCRA, 2013). The removal percentage for TSS/BOD and TP/TN water pollutants are impacted by rainfall event and orifice sizes (Table 5 ).

$$
\begin{aligned}
R= & 0.903+0.0049 \times \text { HRT } \\
& (\text { for TSS } / \text { BOD }, \text { for HRT }>1 \mathrm{hr}) \\
R= & 0.511+0.00935 \times \text { HRT } \\
& (\text { for TP } / \text { TN }, \text { for HRT }>1 \mathrm{hr})
\end{aligned}
$$

Where, R: Removal amount; HRT: Hydraulic Retention Time

The removal percentage decreases as the rainfall amount increases. $0.5 \%$ orifice size shows highest removal percentage than other orifice sizes. The water pollutant load removal amount shows almost the same simulation results though the hydraulic retention time for $0.5 \%$ orifice size is longer than other orifice size. Because the total load computed at monitoring site depends on the total inflow volume that are almost same shown in Table 5 . In other words, for the comparison of water pollutant concentration remained at monitoring site, the concentration for water pollutants with bigger orifice size (i.e. $2 \%$ ) is smaller than other smaller orifice size (i.e. 0.5 and $1 \%$ ) because the concentration depends on the hydraulic retention time that is longer for $2 \%$ orifice size. For measured and 1 year design storm events, the removal percentage show high values that are 94 and 86 percentage for TSS/BOD and 82 and 67 percent for TP/TN, respectively. The reason is that the original $\mathrm{BMP}$ size is built on the 5 year design storm peak inflow and total volume. Table 5 also indicates that removal percents for 5 
year design storm event have 76 percent for TSS/BOD and 53 percent for TN/TP.

\section{Summary and conclusion}

The urbanization result in water quantity and quality problems that are occurred from NPS pollution. Due to the limitation of data available for flood reduction and water quality improvement, it is very difficult to develop the integrated models that consider runoff, water pollutant, and BMP implements. In this study, several procedures were performed with the measured rainfall and runoff as follows: 1) watershed delineation and SWMM input data preparation; 2) SWMM model verification for measured storm water flows and loadings; 3) Evaluation of BMPs (small serial dams) for reducing urban flood and water pollutants for design storm events $(1,5,10,25,50$, and 100 years). The SWMM model was verified based on several criteria indexes that include $R^{2}$, NSE, MRE, peak flow, and peak time. The four composite SWSCS on the north tributary and four SWSCs on the south tributary give the largest reduction of peak flows for 25, 50, and 100 design storms, and the first SWSC shows the highest peak flow reduction compared with other SWSCs. Also, sensitivity analysis is performed to evaluate the impact of peak flow, total volume, and water pollutant change with different sizes of orifice. The sensitivity analysis results indicate that orifice size $0.5 \%$ is more effective than other orifice sizes for peak flow reduction for measured storm event and 1 year design storm event and $0.5 \%$ and $1 \%$ orifice size show similar reduction with 5 year design storm event. Also, orifice size $2 \%$ provides more percentage reduction of water pollutants with three storm events.

The conclusions are as follows: (1) small serial SWSCs are relatively effective for managing the peak flow by spreading out the percentage reduction in limited urbanized areas; (2) the use of small footprint structures in series can obtain potentially cost-effective peak flow reductions; (3) the importance of the timing of peak flows originating from two tributaries with differently sized and shaped drainage areas resulted in different times to peak for storm flows; (4) Each of four storm water structures controls (SWSCS) on two tributaries that are recommended as a reasonable number of SWSCs in this study reduced the peak flow by $71.3,59.1,47.8,34.2$, 23.3, and $14.3 \%$ more than the simulated peak flow without small serial dams at a monitoring site for 1, 5, 10, 25,50 , and 100 -year return interval design storm events; (5) the counter-intuitive results show that the use of more structures was not better because of the consistent match of two different peak times due to delay; and (6) the runoff generated from the use of design storms does not guarantee the simulation results, because the design storms do not mimic the phenomena of storm water generated by precipitation.

\section{Acknowledgement}

The author would like to acknowledge the contributions of Larry M. Hauck at Texas Institute for Applied Environmental Research. Some contents of this paper are reorganized and extracted from technical report Appendix A (Urban Modeling of San Angelo) of UCRA (2013).

This research was supported by Daegu University Research Grant, 2020.

\section{Data Availability Statement}

The data that support the findings of this study are available from the UCRA. Restrictions apply to the availability of these data, which were used under license for this study.

\section{References}

Barco J., Wong K.M. and Stenstrom M.K. (2008). Automatic calibration of the U.S. EPA SWMM model for a large urban catchment. Journal of Hydraulic Engineering, ASCE, 134(4), 466-474. doi: http://dx.doi.org/10.1061/(ASCE)07339429(2008)134:4(466).

Bicknell B.R., Imhoff J.C., Kittle J.L. Jr., Donigian A.S. Jr. and Johanson R.C. (1997). Hydrological Simulation ProgramFortran, User's manual for version 11, U.S. Environmental Protection Agency, National Exposure Research Laboratory, Athens, Ga., EPA/600/R-97/080, 755 p.

Cameron A.C., and Windmeijer F.A.G. (1997). An R-squared measure of goodness of fit for some common nonlinear regression models. Journal of Econometrics, 77(2), 329-342.

Camorani G., Castellarin A. and Brath A. (2005). Effects of landuse changes on the hydrologic response of reclamation systems. Physics and Chemistry of the Earth, 30, 561-574. doi: 10.1016/j.pce.2005.07.010.

Change C.H., Wen C.G. and Lee C.S. (2008). Use of intercepted runoff depth for stormwater runoff management in industrial parks in Taiwan. Water Resources Management, 22, 1609-1623. doi: 10.1007/s11269-008-9245-9.

Choi K. and Ball J.E. (2002), Parameter estimation for urban runoff modelling. Urban Water, 4, 31-41. doi: 10.1016/S1462-0758(01)00072-3.

Cipolla S., Maglionico M. and Stojkov I. (2016), A long-term hydrological modelling of an extensive green roof by means of SWMM, Ecological Engineering, 95, 876-887. https://doi.org/10.1016/i.ecoleng.2016.07.009

COSA (City of San Angelo) (2010). The GIS land use/land cover dataset provided electronically by the COSA's drafting \& survey division.

Debo, T.N., and Reese A.J. (2002). Municipal Stormwater Management, Second Edition, CRC Publishers, Boca Raton, Fl.

Dongquan Z., Jining C., Haozheng W., Qingyuan T., Shangbing C. and Zheng S. (2009). GIS-based urban rainfall-runoff modeling using an automatic catchement-discretization approcah: a case study in Macau. Environmental Earth Sciences, 59, 465-472. doi: 10.1007/s12665-009-0045-1.

Elliott, A.H., Spigel R.H., Jowett I.G., Shankar S.U. and Ibbitt R.P. (2010). Model application to asses effects of urbanisation and distributed flow controls on erosion potential and baseflow hydraulic habitat. Urban Water Journal, 7(2), 91107. doi: 10.1080/15730620-903447605.

Frederick, R.H., Myers V.A. and Auciello E.P. (1977). Five to 60 Minute Precipitation Frequency for the Eastern and Central United States, Technical Memorandum NWS HYDR0-35, pp. 1-36, NOAA, National Weather Service, Silver Spring, MD.

Geo Community (2012). http://data.geocomm.com/catalog/US/61085/2658/index.ht $\mathrm{ml}$ [Access March 27 2012] 
Hershfield D.M. (1961). Rainfall Frequency Atlas of the United States for Durations from 30 minutes to 24 hours and return periods from 1 to 100 years. Tech. Rep. 40, pp. pp. 1-60, U.S. Weather Bureau, U.S. Department of Commerce, Washington D.C.

Huber W.C. and Dickson R.E. (1988). Storm Water Management Model User's Manual, Version 4, EPA/600/3-88/001, Environmental Protection Agency, Athens, GS.

Jang, S., Cho M., Yoon J., Yoon Y., Kim S., Kim G., Kim L. and Aksoy H. (2007). Using SWMM as a tool for hydrologic impact assessment. Desalination, 212, 344-356. http://dx.doi.org/10.1016/j.desal.2007.05.005.

Jat M.K., Khare D., Garg P.K. and Shankar V. (2009). Remote sensing and GIS-based assessment of urbanisation and degration of watershed health, Urban Water Journal, 6(4), 251-263. doi: 10.1080/15730620801971920.

Kim, H., Pak G., Jun H., Kim S. and Yoon J. (2010). Distributed modelling of urban runoff using a meta-channel concept. Water Science and Technology, 2707-2715. doi: 10.2166/wst2010.187.

Kovacs A. and Clement A. (2009). Impacts of the Climate Change of Runoff and Diffuse Phosphorus Load to Lake Balaton (Hungary). Water Science and Technology, 59(3), 417-423. doi: 10.2166/wst.2009.883.

Lee D.J., Choi J.H., Chung J., Lee Y.W. and Kim Y.I. (2009). Effect of infiltration and inflow in dry weather on reducing the pollution loading of combined sewer overflows. Environmental Engineering Science, 26(5), 897-906. doi: 10.1089/ees.2008.0038.

Liu Y., Ahiablame L.M., Bralts V.F. and Engel B.A. (2015). Enhancing a rainfall-runoff model to assess the impacts of BMPs and LID practices on storm runoff. Journal of Environmental Management, 147, 12-23.

Lowe S.A. (2009). Sanitary sewer design using epa storm water management model (SWMM). Computer Applications in Engineering Education, 18(2), 203-212. doi: 10.1002/cae. 20123.

Lucas W.C. (2010). Design of integrated bioinfiltration-detention urban retrofits with design storm and continuous simulation methods. Journal of Hydrologic Engineering, 15(6), 486-498. doi: http://dx.doi.org/10.1061/(ASCE)HE.1943-5584.0000 137.

Magill N. and Sansalone J. (2010), Distribution of particulatebound metals for source area snow in the Lake Tahoe Watershed. Journal of Environmental Engineering, 136(20), 185-193, http://dx.doi.org/10.1061/(ASCE)EE.19437870.0000146 .

Movahedinia M., Samani J., Barakhasi F. and Taghvaeian S. (2019). Simulating the effects of low impact development approaches on urban flooding: a case study from Tehran, Iran. Water Science \& Technology, 80(8), 1591-1600. https://doi.org/10.2166/wst.2019.412.

Nash J.E. and Sutcliffe J.V. (1970). River flow forecasting through conceptual models part I - A discussion of principles, Journal of Hydrology, 10(3), 282-290. doi: http://dx.doi.org/10.1016/0022-1694(70)90255-6.

Neitsch S.L., Arnold J.G., Kiniry J.R., Srinivasan R. and Williams J.R. (2004), Soil and Water Assessment Tool Input/Output File Documentation Version 2005, Soil and Water Research Laboratory, Agricultural Research Service, Temple, Texas.

Park S.Y., Lee K.W., Park I.H. and Ha S.R. (2008). Effect of the aggregation level of surface runoff fields and sewer network for a SWMM simulation. Desalination, 226, 328-337. doi: http://dx.doi.org/10.1016/j.desal.2007.02.115.
Piro P., Carbone M., Garofal G. and Sansalone J.J. (2010). Management of combined sewer overflows based on observation from the urbanized liguori catchement of Cosenza, Italy. Water Science and Technology, 61(1), 135143. doi: 10.2166/wst.2010.805.

Pomeroy C.A., Postel N.A., O'Neill P.A. and Roesner L.A. (2008). Development of storm-water management design criteria to maintain geomorphic stability in Kansas City metropolitan area streams. Journal of Irrigation and Drainage Engineering - ASCE, 134(5), 562-566. doi: http://dx.doi.org/10.1061/(ASC E)0733-9437(2008)134:5(562).

Renard K.G., Foster G.R., Weesies G.A., McCool D.K. and Yoder D.C. (1997). Predicting Soil Erosion By Water: A Guide To Conservation Planning With The Revised Universal Soil Loss Equation (RUSLE). U.S. Department of Agriculture, Agriculture Handbook No. 703. pp. 1-404, Washington, D.C.

Rossman L.A. (2009). Storm Water Management Model User's Manual Version 5.0. EPA/600/R-05/040, Water Supply and Water Resources Division, National Risk Management Research Laboratory, Cincinnati, $\mathrm{OH}$.

Sharifan R.A., Roshan A., Aflatoni M., Jahedi A. and Zolghadr M. (2010). Uncertainty and sensitivity analysis of SWMM model in computation of manhole water depth and subcatchment peak flood. Procedia Social and Behavioral Science, 2, 77397940. doi: 10.1016/j.sbspro.2010.05.205.

Smith D., Li J. and Banting D. (2005). A PCSWMM/GIS-based water balance model for the reesor creek watershed. Atmospheric Research, 77 388-406. doi: 10.1016/j.atmosres.2004.12.010.

Taghizadeh S., Khani S. and Rajaee T. (2021), Hybrid SWMM and particle swarm optimization model for urban runoff water quality control by using green infrastructures (LID-BMPs). Urban Forestry \& Urban Greening, 60. https://doi.org/ 10.1016/j.ufug.2021.127032.

Tsihrintzis V.A. and Hamid R. (1998). Runoff quality prediction from small urban catchment using SWMM, Hydrological Processes, 12, 311-329. doi: 10.1002/(SICI)10991085(199802)12:2 <311::AID-HYP579>3.0.CO;2-R.

U.S. Census Bureau. (2010). Available from http://quickfacts.census.gov/qfd/states/48/486447 2.html. [Accessed 10 May 2010].

Upper Colorado River Authority (UCRA). (2013). UCRA Storm Water Management Plan for the City of San Angelo: Development of Best Management Practices-Structural \& Non-Structural Controls, San Angelo, Texas

Zaghloul N.A. and Abu Kiefa M.A. (2001). Neural network solution of inverse parameters used in the sensitivitycalibration analyses of the SWMM model simulations. Advances in Engineering Software, 32, 587-595. doi: http://dx.doi.org/10.1016/S0965-9978(00)00072-7. 